\title{
Exercise-induced Changes in the Clotting Times and Fibrinolytic Activity during Official 1600 and 2000 Meters Trot Races in Standardbred Horses
}

\author{
G. PICCIONE, F. FAZIO, *E. GIUDICE, F. GRASSO, G. CAOLA \\ Department of Morphology, Biochemistry, Physiology and Animal Production. Section of Veterinary \\ Physiology. Faculty of Veterinary Medicine. University of Messina, Messina, Italy. \\ * Department of Veterinary Medical Science - Faculty of Veterinary Medicine. University of Messina, \\ Messina, Italy.
}

Received December 10, 2004

Accepted November 10, 2005

\begin{abstract}
G. Piccione, F. Fazio, E. Giudice, F. Grasso, G. Caola: Exercise-induced Changes in the Clotting Times and Fibrinolytic Activity during Official 1600 and 2000 Meters Trot Races in Standardbred Horses. Acta Vet. Brno 2005, 74: 509-514.

The aim of the study was to investigate the influence of a training program and submaximal exercise on the clotting times (prothrombin time, PT, activated partial prothrombin time, aPTT, thrombin time, TT) and fibrinogen in the horse in order to assess the probable role of physical conditioning in haemostatic processes suggested in jumping and long-distance running horses. We therefore studied 14 Standardbred horses divided into group A (6 horses) and group B (8 horses). The horses had been separately and specifically trained to take part in official 1600 and 2000 meters trot races, respectively. Blood samples were taken before and after the training period and after the official 1600 and 2000 meters trot races, under the following experimental conditions: at rest, immediately after the trial (within 2 minutes) and $30 \mathrm{~min}$ after the trial. Student T-test for paired data to two groups of untrained and trained horses from groups A and B showed a statistically significant decrease in fibrinogen only $(p<0.006$ in group A and $p<0.03$ in group B). During the official 1600 meters trot race (group A), from among the clotting times only fibrinogen showed statistically significant differences $(p<0.001)$; during the official 2000 meters trot race (group B), the clotting times and fibrinogen, with the exception of TT, showed statistically significant differences (from $p<0.05$ to $<0.001$ ). Our results suggest that specific training programs (as submaximal exercise) could influence the haemostatic changes occurring during an athletic competition.
\end{abstract}

Coagulation, fibrinogen, athletic horse, physical exercise

Few studies exist on the relationship between the blood clotting times and exercise. The increase in clotting and fibrinolytic activity due to exercise has been widely documented in humans, both for maximal (Dufaux et al. 1991; Lin et al. 1999; Van den Burg et al. 2000; Hilberg et al. 2003) and near-maximal efforts (Prisco et al. 1998; Hegde et al. 2001 ); in this species, a direct correlation between fibrinolysis and the exercise intensity has been observed (Ferguson et al. 1987). The increased fibrinolytic activity appears to counterbalance the exercise-induced increase in coagulability (Colwell 1986). As regards the equine species, data available on the effects of exercise on the clotting times are not univocal: some researchers have found evidence of fibrinogen degradation with physical activity (Marsh and Gaffney 1980), whereas others have not demonstrated a difference in coagulability or in fibrinolysis (B ayly et al. 1983ab). However, the lack of detection of exercise-induced hypercoagulability could be due to the time of blood sampling: in fact, blood was checked only before and after the exercise, when the clotting times may have returned to the baseline (McKeever et al. 1990). Recent studies have been conducted on the effect of near-maximal effort on the haemostasis of the horse, revealing different results: horses that took part in a long-distance running, did not show changes in hemostatic balance (Piccione et al. 2004a); while horses that underwent an official show jumping (Pic cione

Address for correspondence:

Dr. Giuseppe Piccione

Department of Morphology, Biochemistry,

Physiology and Animal Production Section of Veterinary Physiology

Faculty of Veterinary Medicine, University of Messina

Polo Universitario dell'Annunziata - 98168 Messina - Italy

Phone: +390903503 584-Fax: +390903 503975

E-mail : Giuseppe.Piccione@unime.it

http://www.vfu.cz/acta-vet/actavet.htm 
et al. 2004b) showed an increased blood clotting activity. The equivocal data reported in literature may suggest an impact of physical conditioning on the hemostatic processes, as investigated in humans (Van den Burg et al. 2000). Assuming that the training programs of jumping and long-distance running horses are different from those of the Standardbred, we wished to investigate the influence of the official 1600 and 2000 meters trot races on the clotting parameters (PT, aPTT, TT and fibrinogen) in the horse.

\section{Materials and Methods}

Fourteen Standardbred horses from the same stud farm, average age $5 \pm 3$ years, average body weight $430 \pm 30$ $\mathrm{kg}$, clinically healthy, were fed three times a day: at $07.00 \mathrm{~h}$ on hay, at $01.00 \mathrm{~h}$ on concentrates, and at $19.00 \mathrm{~h} \mathrm{both}$ on hay and concentrates. Horses were divided into two groups, A and B: the two groups had been separately and specifically trained to take part in the official 1600 and 2000 meters trot races respectively; blood samples were taken before and after the training period. The horses from group A took part in the official 1600 meters trot race (average speed $831.4 \mathrm{~m} / \mathrm{min}$. in 1'19“3 time $/ \mathrm{km}$ ), while group B took part in the official 2000 meters trot race (average speed $831.6 \mathrm{~m} / \mathrm{min}$. in 1'20“2 time $/ \mathrm{km}$ ). Blood samples were collected through external jugular venipuncture under the following experimental conditions: at rest, immediately after the trial (within 2 minutes), and $30 \mathrm{~min}$ after the trial. Blood samples collected in tubes containing $3.8 \%$ sodium citrate were centrifuged within 2 hours from the sampling at $2600 \mathrm{rpm}$ for $10 \mathrm{~min}$. The Prothrombin Time (PT), the activated Partial Thromboplastin Time (aPTT), the Thrombin Time (TT), and fibrinogen were immediately assessed from the obtained plasma by means of standard kits made especially for the SEAC Clot 2 coagulometer. The Prothrombin Time kit (code 90000200 , SEAC, Florence, Italy) is based on the assay principle that the addition of an adequately calcified amount tissue factor (factor III) to citrated plasma activates factor VII, inducing the formation of a stable plug. The assay procedure consists of placing $200 \mu \mathrm{l}$ of tissue factor (at environmental temperature) in a test tube preheated to $37^{\circ} \mathrm{C}$, followed by incubation for $5 \mathrm{~min}$ at $37^{\circ} \mathrm{C}$, and subsequently adding $100 \mu \mathrm{lof}$ test plasma. Upon the addition of test plasma, a stopwatch can be started and the clotting time can be measured. The activated Partial Prothrombin Time kit (code 90000180, SEAC, Florence, Italy) is based on the addition of a piastrinic substitute, as phospholipids, a soluble activator and calcium chloride, which induces plug formation. The assay procedure consists of placing $100 \mu \mathrm{l}$ of test plasma, and $100 \mu \mathrm{l}$ of aPTT reagent (preheated to $37^{\circ} \mathrm{C}$ ), respectively, in a test tube preheated to $37^{\circ} \mathrm{C}$, followed by incubation for $3 \mathrm{~min}$ at $37^{\circ} \mathrm{C}$, and adding $100 \mu \mathrm{l}$ of calcium chloride. Upon the addition of calcium chloride, the stopwatch can be started and the clotting time can be measured. The Thrombin Time kit (code 90000221, SEAC, Florence, Italy) is based on the addition of a known amount of thrombin to citrated plasma, by which fibrinogen directly transforms into fibrin. The assay procedure consists of placing $200 \mu \mathrm{L}$ of test plasma in a test tube preheated to $37^{\circ} \mathrm{C}$, followed by incubation for $2 \mathrm{~min}$ at $37^{\circ} \mathrm{C}$, and then adding $200 \mu \mathrm{L}$ of the thrombin reagent. Upon the addition of the thrombin reagent, the stopwatch can be started and the clotting time can be measured. Eventually, the standard kit for the quantitative determination of fibrinogen (code 90000211; SEAC, Florence, Italy) is based on the addition of a relatively large amount of thrombin to diluted citrated plasma, so that the clotting time depends only on the fibrinogen contained in the sample. The assay procedure consists of placing, after the dilution of the sample at 1:10 (100 $\mu$ of plasma $+900 \mu 1$ of buffer), $200 \mu 1$ of diluted plasma in a test tube preheated to $37^{\circ} \mathrm{C}$, followed by incubation for $2 \mathrm{~min}$ at $37^{\circ} \mathrm{C}$, and then adding $100 \mu \mathrm{l}$ of the fibrinogen reagent (preheated to $37^{\circ} \mathrm{C}$ ). Upon the addition of the fibrinogen reagent, the stopwatch can be started and the clotting time can be measured. For this assay only the results in seconds must be converted into $\mathrm{mg} / \mathrm{dl}$ by using a conversion table supplied with the kit.

Student's $t$-test for paired data was applied to the clotting times of untrained horses (before undergoing the 10week training program), and trained horses from groups A and B respectively. Since the intragroup variance was not significant, the statistical elaboration of data was carried out on the mean values of the examined clotting times. The analysis of variance (one-way and repeated measures ANOVA) was applied in order to evaluate the statistically significant differences between the different experimental conditions (at rest vs. immediately after the trial, at rest vs. 30 min after the trial, and immediately after the trial vs. $30 \mathrm{~min}$ after the trial), in both groups A and B. Where ANOVA showed an acceptable level of significance $(p<0.05)$, Bonferroni test was applied for a post hoc comparison.

\section{Results}

Figs 1-4 show the pattern of the examined clotting times, together with the relative standard deviations and statistical significances, obtained before and after the training period in both groups $\mathrm{A}$ and $\mathrm{B}$ of horses and during the different experimental conditions (at rest, immediately after the trial, and 30' after the trial).

Statistically significant differences were observed only for fibrinogen by comparing untrained and trained horses from both groups $\mathrm{A}$ and $\mathrm{B}(p<0.006$ in group $\mathrm{A}$, and $p<0.03$ 

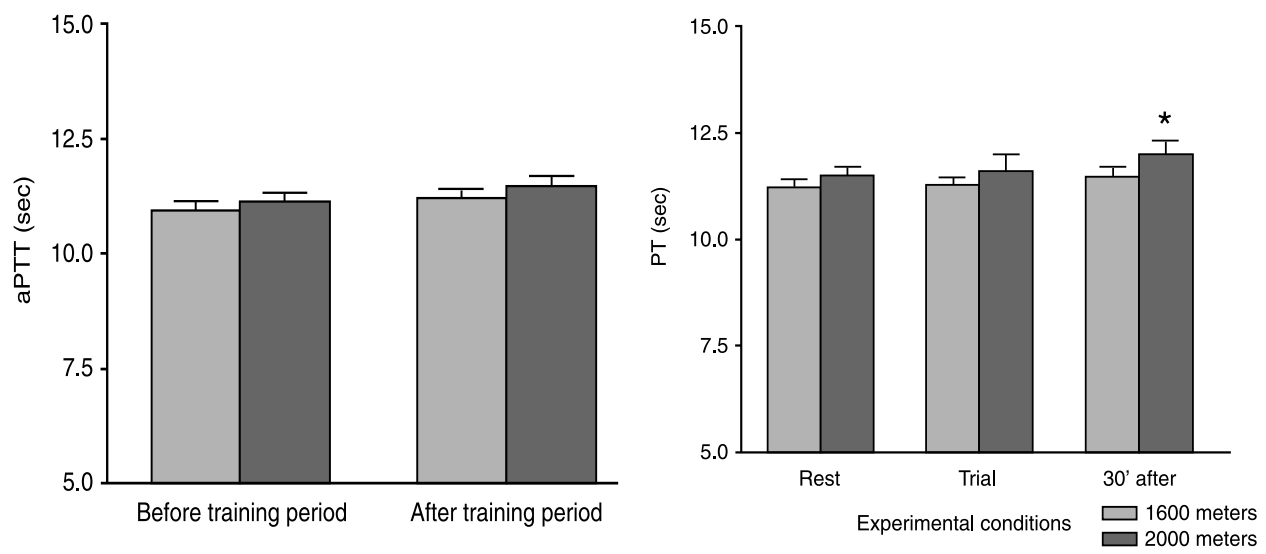

Fig. 1. The pattern of PT, together with the relative standard deviations and statistical significances, obtained before and after the training period both in group A (official 1600 meters trot race), and group B (2 000 meters trot official race) of horses and under different experimental conditions (official 1600 and 2000 meters trot races). Significance: $* V S$ Rest: $(p<0.05)$.
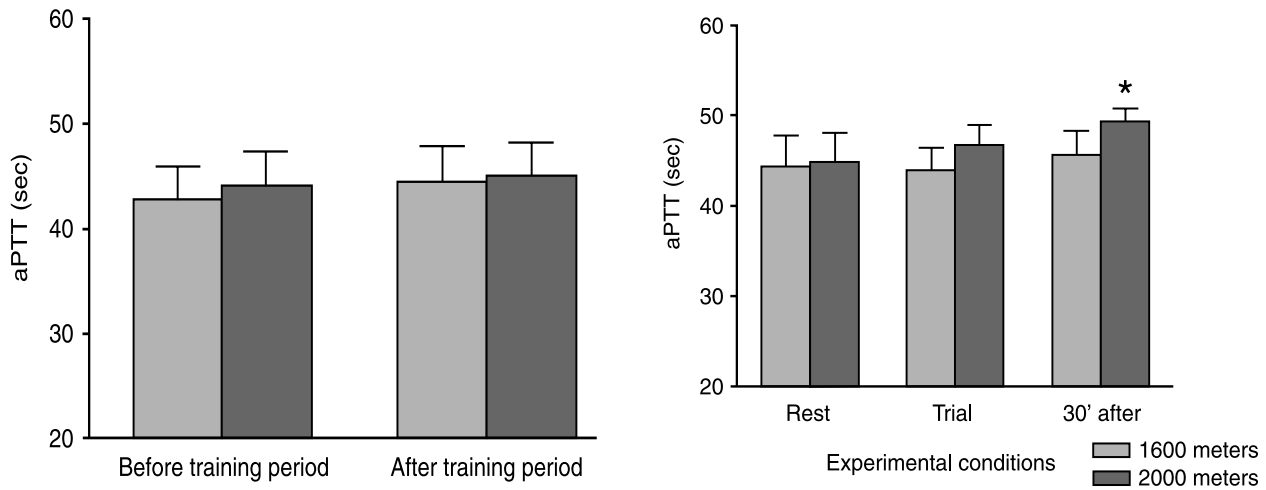

Fig. 2. The pattern of aPTT, together with the relative standard deviations and statistical significances, obtained before and after the training period both in group A (1 600 meters trot official race), and group B (official 2000 meters trot official race) of horses and under different experimental conditions (official 1600 and 2000 meters trot races). Significance: $* V s$ Rest: $(p<0.01)$.

in group B); for group A, only fibrinogen showed statistically significant differences ( $p<$ $0.001)$ immediately and $30^{\prime}$ after the trial compared to rest; in group B, PT $(p<0.05)$ and aPTT $(p<0.01)$ showed statistically significant differences 30 ' after the trial compared to rest, while fibrinogen showed statistically significant differences $(p<0.001)$ immediately and $30^{\prime}$ after the trial compared to rest.

\section{Discussion}

The comparison between untrained and trained horses based on the analysis of the obtained results revealed the same pattern of fibrinogen for both groups A and B, which showed a significant decrease (see above) thus confirming that training induces the enhancement of fibrinolytic activity. The increased fibrinolysis observed after conditioning 

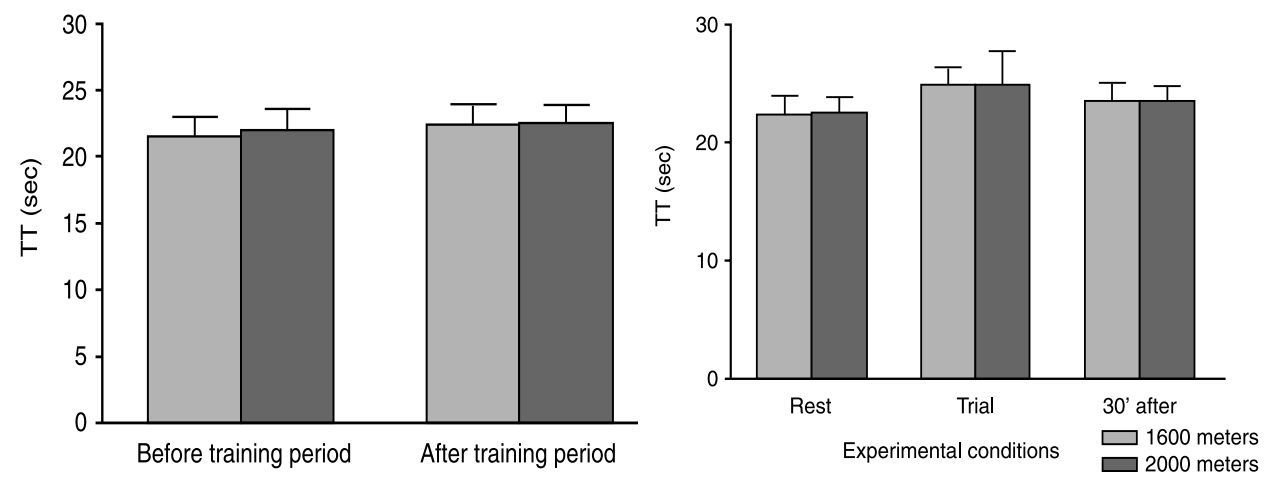

Fig. 3. The pattern of TT, together with the relative standard deviations, obtained before and after the training period both in group A (official 1600 meters trot race), and group B (official 2000 meters trot race) of horses and under different experimental conditions (official 1600 and 2000 meters trot races).
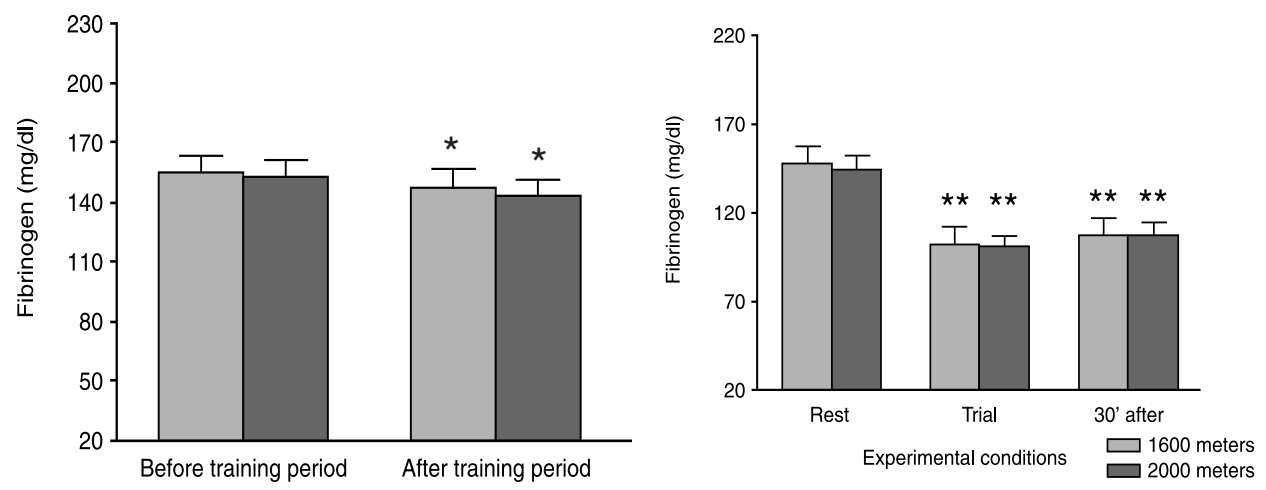

Fig. 4. The pattern of Fibrinogen, together with the relative standard deviations and statistical significances, obtained before and after the training period both in group A (official 1600 meters trot race), and group B (official 2000 meters trot race) of horses and under different experimental conditions (official 1600 and 2000 meters trot races). Significance: ${ }^{*} V S$ Before training period (1600 m: $p<0.006 ; 2000 \mathrm{~m}: p<0.03$ ). $* V S$ Rest $(p<0.001)$

is in agreement with some studies conducted on humans (Stratton et al. 1991; Streiff and Bell 1994; Szymanski et al. 1994) but not with others who did not register any effect of the training on the constitutive and sub-maximal plasma levels of coagulation variables, including fibrinogen (El-Sayed et al. 1995; Van den Burg et al. 1997, 2000). The discrepant results may be due to differences in the experimental setup. In fact, the study of hemostatic variables requires a meticulous standardization, and a delay in assessing blood samples may affect the outcome of the studies (McKeever et al. 1990). In our study, clotting variables were assessed within 2 min from the trial, so as to detect transient changes in haemostasis, while in previous studies which did not reveal exercise-induced modifications, blood samples were collected when values may have returned to baseline levels (Bayly et al. 1983ab). Thus the differences in blood sampling procedures (Huisveld et al. 1992), as well as the intensity (strenuous or sub-maximal), duration and type of training could alter the results. The significant decrease observed in fibrinogen immediately after the trial and 30' after the trial compared to rest both in the 1600 and 2000 meters competitions, confirms the enhancement of fibrinolytic activity during exercise as 
documented in literature, along with the optimization of blood clotting processes in the equine species as well (Mc Ke ever et al. 1990; Pic cione et al. 2004b). However, the level of this increase correlates with both the intensity and duration of exercise (Rosing et al. 1970; Davis et al. 1976). The importance of the intensity of physical activity in influencing hemostatic balance has been documented in humans; submaximal efforts, contrary to the long-duration efforts, actually did not involve changes in aPTT and PT in this species (Bourey and Santoro 1988). The influence of exercise on the clotting times has been reported in horses (Mc Keever et al. 1990; Domina et al. 1998), in cats (Hartman 1972), and in humans (Bourey and Santoro 1988). Changes in hemostatic balance consequent upon exercise have been widely documented, but it is still unclear how hemostatic mechanisms actually respond to this stimulus in the equine species. The statistically significant increase observed for PT and aPTT during the 2000 meters competition is in disagreement with previous researches which showed the shortening of the clotting times in trained trotting horses compared to untrained subjects (Quin tavalla et al. 1994), according to studies on human athletes (Herren et al. 1992; Ibbots on et al. 1993). The lengthening of PT and aPTT has also been observed in long-distance running horses (Monreal et al. 1995), proving that data provided by literature in this field are equivocal.

On the basis of the analysis of the obtained results we may say that the patterns of the clotting times and fibrinogen in response to submaximal efforts are influenced by specific training programs, which should condition the hemostatic changes occurring during an athletic competition. The knowledge of changes which affect hemostatic balance is therefore essential for monitoring the hemostatic adjustments induced by physical exercise in the athletic horse, as well as for a proper interpretation of the critical circulatory situations which commonly occur in the equine species.

\section{Změny ve srážlivosti krve a fibrinolýze v závislosti na zátěži u dostihových koní při dostihu 1600 a 2000 metrů}

Cílem této studie bylo zjistit vliv tréninku a submaximální zátěže na srážlivost krve (PT, aPTT, TT) a koncentraci fibribnogenu u koní, za účelem zjištění vlivu fyzické přípravy na předpokládané hemostatické procesy u skokových a vytrvalostních koní. Studovali jsme 14 dostihových koní rozdělených do skupiny A (6 koní) a skupiny B (8 koní). Koně byli různým způsobem trénováni na dostih 1600 a $2000 \mathrm{~m}$. Vzorky krve byly odebírány před a po tréninku a dále pak po dostizích na 1600 a 2000 metrů následujícícím způsobem: v klidu, bezprostředně po dostizích (během 2 minut) a 30 minut po nich. Studentův párový $t$-test obou skupin, trénovaných (skupina A) a netrénovaných koní (skupina B) prokázal statisticky významné snížení jen u koncentrace fibrinogenu $(p<0,006$ u skupiny A a $p<0,03$ u skupiny B). Při dostihu na 1600 m (skupina A) se statisticky významně zvýšila jen koncentrace fibrinogenu $(p<0.001)$. Při dostihu na 2000 m (skupina B) byl zjištěn statisticky významný rozdíl jak v koncentraci fibrinogenu tak u ukazatelů srážlivosti krve s výjimkou TT (od $p<0.05$ do $p<0.001$ ). Naše výsledky ukazují, že speciální tréninkové programy, jako submaximální zátěž, mohou ovlivnit hemostatické změny během dostihu.

\section{References}

BAYLY WM, MEYERS KM, KECK MT 1983a: Effects of furosemide on exercise-induced alterations in haemostatic in Thoroughbred horses exhibiting post exercise epistaxis. In: Snow, Persson and Rose (Eds.): Equine Exercise Physiology. Cambridge, England, Granta Editions, pp. 64-70

BAYLY WM, MEYERS KM, KECK MT, HUSTON LJ, GRANT BD 1983b: Exercise-induced alterations in haemostasis in Thoroughbred horses. In: Snow, Persson and Rose (Eds): Equine Exercise Physiology. Cambridge, England, Granta Editions, pp. 336-343

BOUREY RE, SANTORO SA 1988: Interactions of exercise coagulation, platelets and fibrinolysis- a brief review. Med Sci Sports Exerc 20: 439-446 
COLWELL JA 1986: Effects of exercise on platalet function, coagulation and fibrinolysis. Diabetes Metab Rev 1: $501-512$

DAVIS GL, ABILGAARD CF, BERNAUER EM, BRITTON M 1976: Fibrinolytic and hemostatic changes during and after maximal exercise in males. J Appl Physiol 40: 287-92

DOMINA F, GIUDICE E, CATARSINI O 1998: Behaviour of blood coagulation in athletic horses during progressive training. SIDI 4: 35-37

DUFAUX B, ORDER U, LIESEN H 1991: Effect of a short maximal physical exercise on coagulation, fibrinolysis and complement system. Int J Sports Med 12: S38-42

EL-SAYED MS, LIN X, RATTU AJM 1995: Blood coagulation and fibrinolysis at rest and in response to maximal exercise before and after a physical conditioning programme. Blood Coagul Fibrinolysis 6: 747-752

FERGUSON EW, BERNIER LL, BANTA GR, YU-YAHIRO J, SCHOOMAKER EB 1987: Effects of exercise and conditioning on clotting and fibrinolytic activity in men. J Appl Physiol 82: 1416-1421

HARTMAN FA 1972: Changes in the clotting time of the blood of cats as results of exercise. Am J Physiol 80: 716718

HEGDE SS, GOLDFARB AH, HEGDE S 2001: Clotting and fibrinolytic activity change during the $1 \mathrm{~h}$ after a submaximal run. Med Sci Sports Exerc 33: $887-892$

HERREN T, BÄRTSCH P, HAEBERLI A, STRAUB PW 1992: Increased thrombin-antithrombin III complexes after 1 h of physical exercise. J Appl Physiol 73: 2499-2504

HILBERG T, PRASA D, STURZEBECHER J, GLASER D, SCHNEIDER K, GABRIEL HH 2003: Blood coagulation and fibrinolysis after extreme short-term exercise. Thromb Res 109: 271-277

HUISVELD IA, VAN DEN BURG PJM, MEIJER P, HOSPERS JE, VAN VLIET M, MOSTERD WL, BOUMA BN, KLUFT C 1992: Catheter unsuitable for the turn-over products of coagulation, fibrinolysis and platelet activation. Fibrinolysis 6: 78-80

IBBOTSON SH, GOUGH SC, RICE PJ, DAVIES JA, GRANT PJ 1993: The effect of short-term exercise on plasma procoagulant activity in patients with type II (non-insulin-dependent) diabetes and healthy volunteers. Thromb Res 71: 149-158

LIN X, EL-SAYED MS, WATERHOUSE J, REILLY T 1999: Activation and disturbance of blood haemostasis following strenuous physical exercise. Int J Sports Med 20: 149-153

MARSH NA, GAFFNEY PJ 1980: Some observations on the release of extrinsic and intrinsic plasminogen activators during exercise in man. Hemostasis 9: 238-247

MCKEEVER KH, HINCHCLIFF KW, KOCIBA GJ, REED SM, MULLER WW 1990: Changes in coagulation and fibrinolysis in horses during exercise. Am J Vet Res 51: 1335-1339

MONREAL L, ANGLES AM, MONREAL M, ESPADA Y, MONASTEIRO J 1995: Changes in haemostasis in endurance horses: detection by highly sensitive ELISA-tests. Equine Vet J 18: 120-123

PICCIONE G, FAZIO F, GIUDICE E, GRASSO F, CAOLA G 2004a: Changes in hematological parameters and clotting times during a long distance running in the horse. Medycyna Wet 60: 587-590

PICCIONE G, ARCIGLI A, COSTA A, FAZIO F, CAOLA G 2004b: Changes in clotting times and fibrinogen concentration in horses during a show jumping. Slov Vet Res 41: 1-8

PRISCO D, PANICCIA R, BANDINELLI B, FEDI S, CELLAI AP, LIOTTA AA, GATTESCHI L, GIUSTI B, COLELLA A, ABBATE R, GENSINI GF 1998: Evaluation of clotting and fibrinolytic activation after protracted physical exercise. Thromb Res 89: 73-78

QUINTAVALLA F, PETTERINO C, BAGNETTI G, BROUILLETD, SIGNORINI GC 1994: Variazioni del bilancio emocoagulativo in relazione all'esercizio fisico del cavallo trottatore. In: Atti SISVet 48: 89-93

ROSING DR, BRAKMAN P, REDWOOD DR 1970: Blood fibrinolytic activity in man: diurnal variation and the response to varying intensities of exercise. Circ Res 27: 171-184

STRATTON JR, CHANDLER WL, SCHWARTZ RS, CERQUEIRA MD, LEVY WC, KAHN SE, LARSON VG, CAIN KC, BEARD JC, ABRASS IB 1991: Effects of physical conditioning on fibrinolytic variables and fibrinogen in young and old healthy adults. Circulation 83: 1692-1697

STREIFF M, BELL WR 1994: Exercise and haemostasis in humans. Semin Hematol 31: 155-165

SZYMANSKI LM, PATE RR, DURSTINE JL 1994: Effects of maximal exercise and venous occlusion on fibrinolytic activity in physically active and inactive men. J Appl Physiol 77: 2305-2310

VAN DEN BURG PJ, HOSPERS JE, VAN VLIET M, MOSTERD WL, BOUMA BN, HUISVELD IA 1997: Effect of endurance training and seasonal fluctuation on coagulation and finrinolysis in young sedentary men. J Appl Physiol 82: 613-620

VAN DEN BURG PJ, HOSPERS JE, MOSTERD WL, BOUMA BN, HUISVELD IA 2000: Aging, physical conditioning and exercise-induced changes in haemostatic factors and reaction products. J Appl Physiol 88: $1558-1564$ 